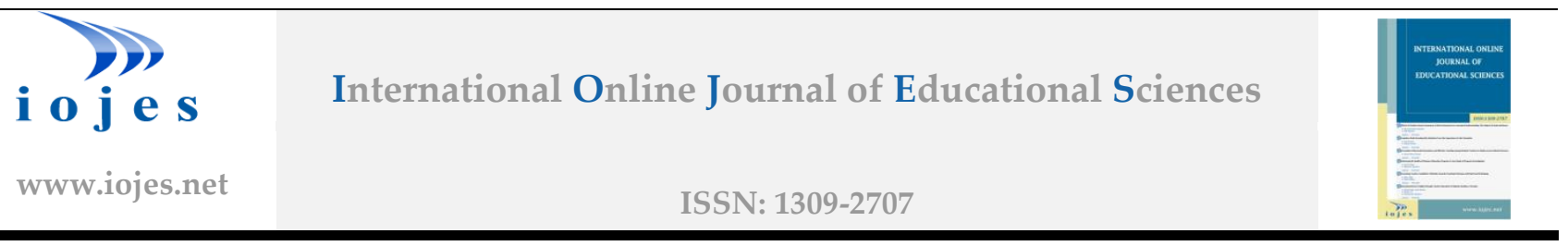

\title{
Solfege Teaching in Higher Music Education in Turkey: Instructors' Perspectives
}

\section{Research Article}

\section{Ozgur EROGLU1}

${ }^{1}$ Atatürk University, State Conservatory of Turkish Music, Department of Turkish Art Music, Erzurum, Turkey, ORCID: 0000-0002-4784-8936

To cite this article: Eroglu, O. (2021). Solfege teaching in higher music education in Turkey: Instructors' perspectives, International Online Journal of Educational Sciences, 13(2), 346-361.

\begin{tabular}{ll} 
ARTICLE INFO & ABSTRACT \\
\hline Article History: & $\begin{array}{l}\text { There is a limited number of studies on solfege teaching in Turkey. The results of these previous } \\
\text { studies show that students' music literacy skills are not sufficient in higher music education. The } \\
\text { purpose of the present study was to explore the professional knowledge, practices and opinions of } \\
\text { Received: 27.04.2020 }\end{array}$ \\
solfege instructors in Turkey. A questionnaire form designed for this study was sent via e-mail to all \\
relevant instructors serving in Turkish universities. Frequency and cross-tabulation analyses were \\
applied on the data obtained from the forms. Findings showed that, student level and student \\
motivation are indicated as factors that decrease the level of success the most. On the other hand, it \\
is figured out that most of the instructors do not plan their own teaching and do not try to use \\
different solfege systems and teaching methods. The majority of them neither search for different \\
method books, technological tools and materials nor try to develop their own method books and \\
materials for a more effective teaching. The results are discussed in the context of the relevant \\
literature and it is concluded that the instructors have a lack of professional knowledge.
\end{tabular}

Keywords:

(C) 2021 IOJES. All rights reserved

Higher music education, ear training, music literacy, sight singing, solfege teaching

\section{Introduction}

Music literacy is perhaps the most important and the most challenging subject in music education. It is important because of being at the base of almost all musical skills, and it is challenging as it requires more analytical processing than any other musical skill.

One of the primary goals of music education, or indeed any educational endeavor, is to produce interested and independent learners. Music literacy is a necessary component of musical independence (Furby, 2008, p. 1).

\footnotetext{
${ }^{1}$ Corresponding author's address: Atatürk Üniversitesi Türk Musikisi Devlet Konservatuvar Telephone: +905555013938

e-mail: ozgur.eroglu@atauni.edu.tr

DOI: https://doi.org/10.15345/iojes.2021.02.003
} 
Brown (1974, p. 52) describes music reading as a means to an end, not a skill to be acquired for its own sake. Just as the ability to read spoken language opens up the world of literature, assists in the interpretation and understanding of current events, and serves to elucidate a multitude of life situations, so the ability to read music increases the opportunity and the capacity to interpret, to understand, and to become beneficially involved in experiences with music.

The concept of music literacy consists of fundamental skills required for a musician, a music researcher and a music teacher. These skills can be listed as sight-singing, dictating and creating melodies. Sight-singing is defined by The Harvard Concise Dictionary of Music and Musicians as "the ability to accurately perform on first reading musical sounds represented by notation" (Kuehne, 2007, p. 115). Walker describes sightsinging as a multifaceted task engaging both cognitive processes and physical skills (Reifinger, 2012, p.27). According to Wunsch (1973, p. 55), a musician needs more than just sensory organs with which to hear. The ear receives soundwaves, but it cannot interpret these vibrations. Even the most sensitive ear can only act as a transmitter to the brain, the nerve center that recognizes and interprets these messages according to established images. In order to record an aural impression, the brain must perceive and coordinate the sounds delivered by the ear.

A research by Norris' (2003) has shown that sight-singing and dictation are related skills. The purpose of dictation, as Michael Rogers states, is "not to produce correct written transcriptions, but to produce a certain kind of listener who can hear sound as a meaningful pattern." Students need to be taught how to listen and for what to listen. "Many aural skills texts have focused on the drill-and-repetition aspects of learning to hear. The weakness of this approach centers on a failure to distinguish between sound events (requiring just ears) and musical events (requiring ears and minds) (Sisley, 2008, p. 1).

Demorest states that, there are numerous pitch systems in teaching sight-singing skills. One system is movable do, which means that do may change depending upon the key of the piece. A similar system utilizes numbers that correspond to the scale degrees changing with the key of the piece. A third system is fixed do, which always keeps do on note $C$ regardless of the key of the piece. Other systems include singing pitch letter names (A, B, C) or singing the pitches on a neutral syllable (e.g., la) (Floyd \& Bradley, 2006, p. 70).

In his research, Daniels (1986) investigated the relationship of sight-reading success with other variables. It is concluded that there is not a correlation between the used solfege system and sight-reading success. However, it is clear that there exists a significant relationship between sight-reading success and instructors' attitude towards solfege teaching.

It is impossible to say that any one solfege system is superior to another. Specific solfege systems should be chosen for specific students, for specific educational objectives, and for specific repertoires. And every solfege system has the honor of being the best system for at least one given purpose (Larson, 1993, p. 115). Music performers and music educators should know the merits and demerits of all systems. If the music education majors had the chance to learn both major solfege systems, and if they were familiar with both systems equally well, they would be able to choose one depending on the situation (Komiyama, 2011, p. 21).

\section{Solfege Instruction in Turkey}

In Turkish higher music education programs, courses which aim to provide music literacy skills are named variously as 'Solfege', 'Musical Hearing-Reading-Writing', 'Western Music Theory and Practice', 'Basic Music Theory and Solfege'.

In Apaydınlı's view (2006, p. 12), solfege instruction is the most essential field of professional music education with its structure aiming behavioral changes related to music theories, musical hearing, musical writing, musical analysis and musical creating. Nart (2013, p. 414) also states that solfege instruction is the 
most important field in music education since the learning outcomes of solfege courses consist of prerequisite skills for other major courses of music education. In their study, Sağer, Gürpınar and Zahal (2013) support this view and conclude that student success in Musical Hearing-Reading-Writing course has a positive effect on their success in other major courses. Karahan (2014, p. 1269) also emphasizes that students' success level in Musical Hearing-Reading-Writing course is an important indicator of their professional achievement.

Even if the importance of solfege instruction is commonly accepted in Turkey, there is a limited number of studies on planning, implementing and evaluating of these courses. Özdemir (2019: 62) highlights that there is a huge discrepancy among instructors on teaching solfege due to the lack of relevant research. Additionally, in Öztürk's view (2010, p. 80), solfege teaching methods are not well-known, and unsystematic solfege teaching cannot go beyond 'note reading' at institutions of higher music education. Özaltunoğlu (2003, p. 43) also states that most of the music educators serving at Turkish universities are regarding solfege teaching as just 'note reading'.

The results of the previous studies on solfege teaching in Turkey show that the students' music literacy skills are not sufficient in higher music education. In his research investigating the resources and methods followed in solfege teaching at conservatories, Yazan (2007) determined that $55 \%$ of the student participants find music dictation very difficult. In a study conducted by Tufan (2012), the students' Musical Aptitude Test scores are compared with the scores from the same test they took after six terms of Musical Hearing-ReadingWriting course. It is seen that there is not a significant difference between the averages of pre-test and posttest scores. In another study, Sağer and others (2013) compared major course scores of music education students and determined that Musical Hearing-Reading-Writing course score average is the lowest with 55 points. In a research by Karahan (2016), it is figured out that significant number of the students failed Musical Hearing-Reading-Writing course. The main reason for failure is determined as the insufficiency of the students' out-of-classroom studies. Karkın and Baş (2016, p. 200) also indicate that student achievement levels in solfege and musical dictation are very low in Turkey and it is necessary to research and resolve this problem.

The purpose of the present study was to explore the professional knowledge, practices and opinions of solfege instructors in Turkey. For this purpose, answers to the following questions were sought:

- How much do instructors know about solfege systems and teaching methods, and which ones do they use in teaching?

- Are the instructors following an instruction plan in their teaching?

- What are the resource books, materials and technological tools used in solfege instruction?

- What are the practices that instructors include in their teaching and which ones are challenging for students?

- What are instructors' views on the achievement level of solfege instruction and the negative factors?

\section{Method}

'Descriptive model' is used in this quantitative study to explore the professional knowledge, practices and opinions of solfege instructors in Turkey. Descriptive model is suitable for research that aims to describe a past or present situation as it is (Karasar, 1999).

\section{Participants}

The research population includes the instructors teaching solfege at institutions of higher music education in Turkey. By searching the websites of all Turkish universities in May 2019, the number of the solfege instructors is determined as 90 in 51 universities and e-mail addresses of all instructors are collected. Since it is possible to reach all of the research population easily, there is no need to select a sample and all of 
the instructors are included into the study. The data collection form is sent to the instructors via e-mail and 37 of them completed and replied the form appropriately.

Twenty-three of the participants are graduated from Faculty of Education, 8 of them are graduated from State Conservatory, 3 of them are graduated from Faculty of Music and Performing Arts, 2 of them are graduated from Faculty of Fine Arts and one of them is graduated from another faculty. Twenty-four of the participants have doctoral degree, 8 of them have master's degree, 2 of them have proficiency in art degree and 3 of them have bachelor degree. Sixteen of the participants are Assistant Professors, 11 of them are Lecturers, 4 of them are Associate Professors, 4 of them Research Assistants and 2 of them are Substitute Instructors. Seventeen of the participants are serving in Faculty of Education, 8 of them are serving in Conservatory, 6 of them are serving in Faculty of Fine Arts, 4 of them are serving in Faculty of Music and Performing Arts and 2 of them are serving in other faculties. Nine of the participants for 1-5 years, 7 of them for 6-10 years, 5 of them for 11-15 years, 14 of them for 16-20 years, 1 of them for 21-25 years and 1 of them for more than 25 years have been teaching solfege at higher education.

\section{Data Collection and Analysis}

The research data is collected through questionnaire form designed by the researcher. While designing the form, information and views which need to be obtained are determined through literature review and the opinions of two field experts. Afterwards, questions which will provide these information and views are arranged consulting with the field experts. Ultimately, the response options for questions are designed in accordance with relevant literature and the questionnaire form is finalized through expert opinions.

Instructions about how to complete the questionnaire form and definitions of terms included are given on the first page of the form. In the first section, there are 7 questions about personal information of the participants. In the second section with 15 questions, it is aimed to receive the instructors' views and information about solfege systems and teaching methods they use, planning and evaluating their instruction, resource books and technological tools they use, the practices they apply in the classroom, achievement level of their teaching and the factors that prevent their teaching from being more effective.

The questionnaire form is sent via e-mail to all relevant instructors $(n=90)$ serving in Turkish universities and 24 of them are replied initially. The form is resent to the instructors who have not replied after one month and 13 forms more are collected. Finally, 37 of the instructors completed and sent the form back.

It is assumed that content validity of the data collection tool is provided as a broad literature review is done and expert opinions are received at each stage during the preparation of the questionnaire. It is accepted that the collected data in the research has enough reliability due to the fact that the results are consulted with the field experts and are mostly in line with the previous research results.

At the data analysis stage, frequency and cross-tabulation analysis are applied on the data collected from questionnaire forms replied by the instructors. The findings are interpreted comparing with the previous research results.

\section{Findings}

The first research question of this study asked: 'How much do instructors know about solfege systems and teaching methods, and which ones do they use in teaching?' A hundred percent of the participants have detailed information about the Fixed Do system, 73\% have about the Movable Do system, 35\% have about the Movable Numbers system. A hundred percent of the participants learned Fixed Do system in their undergraduate education, 32\% learned Movable Do system and 14\% learned Movable Numbers system. Ninety-two percent of the participants are using Fixed Do system in their teaching, 30\% are using Movable Do system and $24 \%$ are using Movable Numbers system. Eighty-four percent of the participants learned Interval 
Memorization method in their undergraduate education, 70\% learned Tonal Degrees method, and 68\% learned Solfege Memorization method. Eighty-seven percent of the participants are using Interval Memorization method in their teaching, $83 \%$ are using Tonal Degrees method and $60 \%$ are using Solfege Memorization method.

The second research question was whether the instructors following an instruction plan in their teaching. Fourteen percent of the participants are not following an instruction plan in their teaching, $46 \%$ are following an instruction plan that designed by their own, 35\% are following a plan that they prepared with their colleagues and $5 \%$ are following a plan designed by someone else.

The third research question asked what the resource books, technological tools and materials used in solfege instruction. As resource book used in the classroom, $89 \%$ of the participants are using solfege books by Lavignac, $49 \%$ are using books by Sun, 30\% are using books by Özgür-Aydoğan, 19\% are using books by Pozzoli, $14 \%$ are using books by Fontaine, $14 \%$ are using books by Allarme, 11\% are using books by Yavuzoğlu, $11 \%$ are using books by Dandelot, $8 \%$ are using books by Ünal, $5 \%$ are using books by Sevgi and 3\% are using books by Comtemporain. Sixty percent of the participants are not using any technological tools in the classroom, $16 \%$ are using projectors, $14 \%$ are using computers, $8 \%$ are using interactive whiteboards, $5 \%$ are using speakers. Fifty-one percent of the participants do not suggest any websites or applications for students to use out of the classroom, 27\% suggest Ear Master application, 16\% suggest Ear Training application, $8 \%$ suggest Perfect Ear application and 8\% suggest teoria.com website.

The fourth research question was: 'What are the practices that instructors include in their teaching and which ones are challenging for students'. As shown in Table 1, interval and chord practices are highly included in both lessons and exams. Additionally, 'Melodic Dictation' and 'Sight-singing' which are highly included in the lessons are also the most challenging practices for students. Rhythm practices are less included in the exams even if they are highly involved in the lessons. 23 participants (\%62) declare that students do not have difficulty in 'Recognizing and Singing Intervals'. However, 17 of these 23 state that 'Sight-singing' is challenging and 14 state that 'Melodic Dictation' is challenging for students.

Table 1. The practices included in the lessons and exams and the challenging practices for students

\begin{tabular}{|c|c|c|c|c|c|c|}
\hline & \multicolumn{2}{|c|}{$\begin{array}{l}\text { Practices } \\
\text { included in } \\
\text { the lessons }\end{array}$} & \multicolumn{2}{|c|}{$\begin{array}{c}\text { Practices } \\
\text { included in } \\
\text { the exams }\end{array}$} & \multicolumn{2}{|c|}{$\begin{array}{c}\text { Challenging } \\
\text { practices for } \\
\text { students }\end{array}$} \\
\hline & $\mathrm{f}$ & $\%$ & $\mathrm{f}$ & $\%$ & $\mathrm{f}$ & $\%$ \\
\hline Recognizing and singing intervals & 36 & 97 & 34 & 92 & 14 & 40 \\
\hline Recognizing and singing chords & 37 & 100 & 33 & 89 & 23 & 66 \\
\hline Recognizing and singing scales & 34 & 92 & 22 & 60 & 6 & 17 \\
\hline Reading rhythmic patterns & 33 & 89 & 16 & 43 & 7 & 20 \\
\hline Rhythmic dictation & 31 & 84 & 24 & 65 & 9 & 26 \\
\hline Singing melodic patterns written with degree numbers & 10 & 27 & 2 & 5 & 3 & 9 \\
\hline Dictating melodic patterns with degree numbers & 9 & 24 & 2 & 5 & 4 & 11 \\
\hline Singing non-rhythmic melodic patterns & 17 & 46 & 4 & 11 & 2 & 6 \\
\hline Dictating non-rhythmic melodic patterns & 16 & 43 & 7 & 19 & 4 & 11 \\
\hline Rhythmic reading with note names & 33 & 89 & 19 & 51 & 3 & 9 \\
\hline Sight-singing & 34 & 92 & 34 & 92 & 24 & 69 \\
\hline Memorizing solfege pieces by repeating & 21 & 57 & 14 & 38 & 5 & 14 \\
\hline Melodic dictation & 30 & 81 & 30 & 81 & 25 & 71 \\
\hline Melodic analysis & 34 & 92 & 18 & 49 & 17 & 49 \\
\hline Creating melodies in tonal structure & 24 & 65 & 5 & 14 & 9 & 26 \\
\hline
\end{tabular}


Finally, the fifth research question asked what the instructors' views on the achievement level of solfege instruction and the negative factors. As shown in Table 2, 43\% of the participants take the view that the overall achievement of solfege teaching in Turkey is at the medium level, $22 \%$ state that it is at the medium-high level. Forty-three percent of the participants hold the view that the achievement of their own solfege teaching is at the medium level and 38\% state that it is at the medium-high level. Thirty-eight percent of the participants declare that the achievement level of their own solfege teaching is higher than the overall achievement level of solfege teaching in Turkey while $8 \%$ suggest vice versa.

Table 2. The cross-match of instructors' views on the overall achievement level of solfege teaching in Turkey and achievement level of their own solfege teaching

\begin{tabular}{|c|c|c|c|c|c|c|c|}
\hline & \multicolumn{5}{|c|}{ Achievement level of your own solfege teaching } & \multirow[t]{2}{*}{ Total } \\
\hline & & Very low & Medium-Low & Medium & Medium-High & $\begin{array}{l}\text { Very } \\
\text { high }\end{array}$ & \\
\hline \multirow{6}{*}{$\begin{array}{l}\text { The overall } \\
\text { achievement level } \\
\text { of solfege teaching } \\
\text { in Turkey }\end{array}$} & Very low & 0 & 0 & 1 & 0 & 0 & 1 \\
\hline & Medium-Low & 1 & 2 & 5 & 1 & 0 & 9 \\
\hline & Medium & 0 & 1 & 9 & 6 & 0 & 16 \\
\hline & Medium-high & 0 & 0 & 1 & 6 & 1 & 8 \\
\hline & Very high & 0 & 0 & 0 & 0 & 0 & 0 \\
\hline & No idea & 1 & 0 & 1 & 1 & 0 & 3 \\
\hline Total & & 2 & 3 & 17 & 14 & 1 & 37 \\
\hline
\end{tabular}

As seen in Table 3, most participants declare 'student motivation' and 'student level' as the factors that have negative effects on the achievement. Almost all of the instructors assume that the factors that are related to themselves do not have negative effects on the achievement. Sixty percent of the participants state that the instructor level does not have a negative effect on the achievement, although they do not have sufficient information about the 'Moving Numbers' system.

Table 3. Instructors' views on the factors that have negative effects on the achievement of their own solfege teaching

\begin{tabular}{lcc}
\hline & $\mathbf{f}$ & $\mathbf{\%}$ \\
\cline { 2 - 3 } Course duration & 16 & 44 \\
Physical conditions & 7 & 19 \\
Resource books & 3 & 8 \\
Software and applications & 9 & 25 \\
Instruction plan & 6 & 17 \\
Student motivation & 28 & 78 \\
Instructor motivation & 1 & 3 \\
Student level & 27 & 75 \\
Instructor level & 2 & 6 \\
\hline
\end{tabular}

\section{Discussion}

The purpose of this study was to explore the professional knowledge, practices and opinions of solfege instructors in Turkey. In this section, the findings are discussed in the context of the relevant literature.

In their teaching, almost all of the instructors are using the solfege systems and teaching methods applied in their undergraduate education. Consistent with this result, it is concluded in Özdemir's study (2019) that great majority of the instructors do not take any pedagogic education on solfege teaching and they use the systems and methods applied in their undergraduate education. According to the results of the Işıldar's (2004) research on solfege teaching, instructors generally use traditional teaching methods and very few of them apply different methods. 
'Fixed Do' system is the most used one both in the instructors' teaching process and in their undergraduate education. Although most of the instructors are applying 'Tonal Degrees' method in their teaching, very few of them use 'Movable Numbers' system which is quite suitable for this method. In Özaltunoğlu's research (2011) with the students from Faculty of Fine Arts Music Department, the experimental group which practiced dictation with 'Movable Numbers' system showed higher success at a significant level than the control group practiced with 'Fixed Do' system. In parallel with this result, in his experimental study on comparing solfege systems, Öztürk (2010) determined that teaching with 'Movable Numbers' system provided a higher achievement than teaching with 'Fixed Do' system.

Most of the instructors are following an instruction plan in their teaching process. Nevertheless, it can be concluded that there are some deficiencies in planning solfege instruction due to the fact that less than half of the instructors are using the plan designed by their own. Also Özbek $(2003$, p. 1) states that there isn't a comprehensive instructional designing study on solfege teaching in Turkey and solfege instruction is usually based on superficial observation and personal experience.

As a classroom resource book, solfege books by Lavignac are much more widely used than the others. Also according to the Iş̧ldar's (2004) research, books by Lavignac are mostly used classroom resource books in solfege teaching in music teacher training institutions. Also Özbek (2003) supports the same result in his research. It is remarkable that the solfege books by Lavignac are still used so widely as a resource book in solfege classes in Turkey today. It cannot be assumed that a solfege book prepared in another century and in accordance to the needs of another community is appropriate for music education in $21^{\text {st-century Turkey. }}$

Most of the instructors do not use any technological tools and materials in their teaching. Projection device is the most used one. The most suggested application for students to use out of the classroom is 'Ear Master'. Most of the solfege instructors who participated in Özdemir's research (2019) indicate that using technological materials in and out of the classroom will increase student success and facilitate learning. Özdemir also determined that the most preferred application by the instructors is 'Ear Master'. Although there are many similar applications, Ear Master has a Turkish language option and this may be the reason for its preference.

The most included practices in the lessons are 'recognizing and singing chords, intervals and scales', 'sight-singing', 'melodic analysis', 'rhythm practices' and 'melodic dictation'. The most used practices in the exams are 'recognizing and singing intervals', 'sight-singing', 'recognizing and singing chords' and 'melodic dictation'. Also according to Özdemir's study (2019), almost all of the instructors include melodic dictation and sight-singing in the exams. In addition, the fact that some of the practices - like rhythm practices included much more in the lessons are included in the exams much less may mean that there are some deficiencies in the planning of solfege instruction.

According to the views of the participants, 'melodic dictation' and 'sight-singing' are the practices that students have the most difficulty in. Consistent with this result, results of the studies by both Ermiş (2009) and Yazan (2007) indicate that 'melodic dictation' is one of the most challenging practices for students. The reason for this may be the insufficiency of the theoretical and auditory background necessary for melodic dictation.

Nearly half of the participants state that, although 'recognizing and singing intervals' is not a challenging practice for students, they have difficulty in 'sight-singing' and 'melodic dictation'. This result may imply that, contrary to common argument, interval practices do not have a significant positive effect on 'melodic dictation' and 'sight-singing' success. However, Özdemir (2019, p. 51) claims that interval practices will make a significant positive effect on students' music literacy skills. The deficiency of this view is to ignore that the same intervals between different degrees of a scale (for example: in G major scale, 'sol-si' and 're-fa\#' major-third intervals) have different auditory effects. 


\section{Conclusion and Recommendations}

\section{Conclusion}

Considering the results, it is clearly understood that solfege instructors generally have a lack of professional knowledge. Student level and student motivation are indicated as factors that decrease the level of success. Most instructors assume that factors related to themselves do not have a negative impact on achievement. However, it is evident from the results that most of the instructors do not plan their own teaching and do not search for different solfege systems and teaching methods. The majority of them neither develop their own materials and method books, nor search for different method books, technological tools and materials for a more effective teaching.

\section{Recommendations}

- There is a need for further studies searching solfege teaching in Turkey from different perspectives. Especially, studies on increasing the student motivation can play an important role to increase the overall achievement of music education. In addition, researches from the students' perspective are essential.

- Instructors should be motivated to study on different solfege systems and teaching methods and include these in their teaching. In order to raise awareness, presentations on this subject should be made in music education conferences and seminars should be organized for academic staff.

- Courses on solfege teaching should be included in master's and doctoral programs.

- Instructors also should be aware of the significance of instructional planning and learn how to design their courses.

- Technological tools and materials should be effectively included in teaching and solfege classrooms should be equipped so as to utilize technology. 
Ek-1 Bilgi ve Görüş Formu

\section{BILLGI VE GÖRÜŞ FORMU}

Bu form, ülkemizde mesleki müzik eğitimi verilen yükseköğretim kurumlarındaki "Batı Müziği Solfej” eğitimiyle ilgili bir araştırma için veri toplamak amacıyla hazırlanmıştır. Forma isim yazılmayacak ve araştırmaya katılan öğretim elemanlarının isimleri kesinlikle gizli tutulacaktır. Formlardan elde edilecek veriler, başka hiçbir amaç için kullanılmayacaktır.

Formda, kişisel bilgilerle ilgili soruların yer aldığı 1 . Bölümde 7 , solfej öğretimine ilişkin bilgi ve görüşlerle ilgili soruların yer aldığı 2. Bölümde ise 15 olmak üzere, toplam 22 soru bulunmaktadır. Öncelikle tanımları okuduktan sonra, tüm sorulara en uygun cevap veya cevapları işaretleyiniz. Gerek duyduğunuz sorularda şıkların sonuna eklemeler yapabilirsiniz. Katkılarınız için teşekkür ederim.

Araştırmacı

\section{Tanimlar}

- "Sabit-Do" Sistemi: Solfej parçalarının sabit nota isimleriyle (Do, Re, Mi, ...) seslendirilmesi

- "Aktarımlı-Do" Sistemi: Solfej parçalarının, hangi tonda olduğu fark etmeksizin, birinci derece notasının Do, ikinci derece notasının Re, üçüncü derece notasının $\mathrm{Mi}$, vb. şeklinde isimlendirilerek seslendirilmesi

- "Aktarımlı Numaralar" Sistemi: Solfej parçalarının, hangi tonda olduğu fark etmeksizin birinci derece notasının "Bir", ikinci derece notasının "İki", üçüncü derece notasının "Üç", vb. şeklinde isimlendirilerek seslendirilmesi

- "Aralık Ezberleme” Yöntemi: Küçük ikili, büyük üçlü, tam beşli, vb. aralıkların teorik ve işitsel olarak ezberlenmesiyle, aralık seslendirmeye yönelik alışkanlık kazanılması

- “Solfej Parçası Ezberleme" Yöntemi: Solfej parçalarının bir çalgı (genellikle piyano) yardımıyla tekrar tekrar seslendirilerek ezberlenmesiyle, aralık seslendirmeye yönelik alışkanlık kazanılması

- “Tonal Dereceler” Yöntemi: Majör ve minör tonların derecelerinin özellikleri ve etkilerinin kavranmasıyla, derece seslendirmeye yönelik alışkanlık kazanılması

- Ezgi Kalıpları: Genellikle iki ila beş sesten oluşan, ritim öğesi içermeyen, majör veya minör olarak tanımlanabilecek nota grupları 


\section{Bölüm: Kişisel Bilgiler}

(UYGUN SEÇENEĞİ, ÖNÜNDEKI KUTUCUĞA TIKLAYARAK IŞARETLEYINIIZ)

1. Kadro unvaninız

$\square$ Prof. $\square$ Doç. $\quad \square$ Dr. Öğr. Üyesi $\square$ Öğr. Gör. $\quad \square$ Araş. Gör. $\quad \square$ Saat Ücretli Öğr. Gör.

2. En son aldığınız akademik derece

$\square$ Doktora $\quad \square$ Sanatta Yeterlilik $\quad \square$ Yüksek Lisans $\quad \square$ Lisans

3. Görev yapmakta olduğunuz okul türü

Eğitim Fak. $\quad \square$ Güzel Sanatlar Fak.

Müzik ve Sahne San. Fak. $\quad \square$ Konservatuvar

Diğer

4. Lisans derecesini aldığınız okul türü

$\square$ Eğitim Fak. $\square$ Güzel Sanatlar Fak. $\square$ Müzik ve Sahne San. Fak. $\quad \square$ Konservatuvar $\square$ Diğer

5. Lise derecesini aldığınız okul türü

$\square$ Güzel Sanatlar Lisesi $\square$ Müzik ve Sahne Sanatları Lisesi $\quad \square$ Diğer

6. Üniversite düzeyinde kaç yıldır ders veriyorsunuz?

$\square 1-5$ yıl $\quad \square 6-10$ yıl $\quad \square 11-15$ yıl $\quad \square 16-20$ yıl $\quad \square 21-25$ yıl $\quad \square 25$ yıldan fazla

7. Üniversite düzeyinde kaç yıldır solfej eğitimi veriyorsunuz?
$\square 1-5$ yıl
$\square 6-10$ yıl
$\square 11-15$ yıl
$\square 16-20$ y1
$\square 21-25$ yll
$\square 25$ yıldan fazla

II. Bölüm: Solfej Ĕ̆itimine ve Öğretim Yöntemlerine İlişkin Bilgi ve Görüşler

1. Aşağıdaki solfej sistemlerinin hangileri hakkında ayrıntılı bilgi sahibisiniz?

(YÖNTEMLERIN AÇIKLAMALARI ILLK SAYFADA YAPILMIŞTIR.)

(BIRDEN FAZLA SEÇENEĞİ IŞARETLEYEBILIRSINIZ.)

(İSARETLEDIGĞINIZ YÖNTEMLE ILGILI OLUMLU VEYA OLUMSUZ DÜŞÜNCELERINİZ VARSA EKLEYINIZ.)

$\square$ Sabit-Do sistemi

- Olumlu yanları:

- Olumsuz yanları:

$\square$ Aktarıml1-Do sistemi

- Olumlu yanları:

- Olumsuz yanları:

$\square$ Aktarımlı Numaralar sistemi

- Olumlu yanları:

- Olumsuz yanları:

2. Almıș olduğunuz solfej eğitiminde, hangi solfej sistemlerini öğrendiniz?

(BIRDEN FAZLA SEÇENEĞİ IŞARETLEYEBILIRSINIZZ.)

$\square$ Sabit-Do sistemi

$\square$ Aktarıml1-Do sistemi

$\square$ Aktarımlı Numaralar sistemi

Diğer (varsa ekleyiniz): 
3. Vermekte olduğunuz solfej eğitiminde, hangi solfej sistemlerini kullanıyorsunuz?

(BIRDEN FAZLA SEÇENEĞİ IŞARETLEYEBILIRSINIZ.)

Sabit-Do sistemi

$\square$ Aktarıml1-Do sistemi

Aktarımlı Numaralar sistemi

$\square$ Diğer (varsa ekleyiniz):

4. Almıș olduğunuz solfej eğitiminde, hangi solfej öğretim yöntemlerini öğrendiniz? (BIRDEN FAZLA SEÇENEĞİ IŞARETLEYEBILIRSINIZ.)

$\square$ Aralık Ezberleme yöntemi

$\square$ Solfej Parçası Ezberleme yöntemi

$\square$ Tonal Dereceler yöntemi

Diğer (varsa ekleyiniz):

5. Vermekte olduğunuz solfej eğitiminde, hangi solfej öğretim yöntemlerini kullanıyorsunuz?

(BIRDEN FAZLA SEÇENEĞİ IŞARETLEYEBILIRSINIIZ.)

$\square$ Aralık Ezberleme yöntemi

$\square$ Solfej Parçası Ezberleme yöntemi

$\square$ Tonal Dereceler yöntemi

$\square$ Diğer (varsa ekleyiniz):

6. Vermekte olduğunuz solfej eğitiminde, takip ettiğiniz; öğrenme hedeflerini, haftalık ders içeriklerini, değerlendirme kriterlerini ve ders materyallerini kapsayan bir "ders öğretim planı" var mı? Varsa kim tarafından hazırlanmış?

$\square$ Yok - Herhangi bir ders öğretim planını takip etmiyorum

$\square$ Var - Benim hazırladığım bir ders öğretim planını takip ediyorum

$\square$ Var - Meslektaşlarımla ortak olarak hazırladığımız bir ders öğretim planını takip ediyorum

$\square$ Var - Başkası tarafından hazırlanmış bir ders öğretim planını takip ediyorum

7. Vermekte olduğunuz solfej eğitiminde, derste kullandığınız kitaplar/kaynaklar var mı? Varsa siralayınız.

$\square$ Yok

Var:

8. Vermekte olduğunuz solfej eğitiminde, derste kullandığınız teknolojik araç-gereçler var mı? Varsa siralayınız.

$\square$ Yok

Var:

9. Vermekte olduğunuz solfej eğitiminde, öğrencilere ders dışında kullanmaları için yardımcı olarak önerdiğiniz internet siteleri veya bilgisayar/telefon uygulamaları var mı? Varsa sıralayınız.

$\square$ Yok

Var: 
10. Vermekte olduğunuz solfej eğitiminde, hangi çalışmalara yer veriyorsunuz? (BIRDEN FAZLA SEÇENEĞİ IŞARETLEYEBILIRSINIIZ.)

$\square$ Aralık tanıma-seslendirme

$\square$ Akor tanıma-seslendirme

$\square$ Dizi tanıma-seslendirme

$\square$ Ritim kalıplarını okuma

$\square$ Ritim diktesi yazma

Derece numaralarıyla $(1,2,3, \ldots)$ yazılmış (ritimsiz) ezgi kalıplarını seslendirme

$\square$ Derece numaralarıyla $(1,2,3, \ldots)$, (ritimsiz) ezgi kalıpları diktesi yazma

$\square$ Dizek üzerinde, notalarla yazılmış (ritimsiz) ezgi kalıplarını seslendirme

Dizek üzerinde, notalarla (ritimsiz) ezgi kalıpları diktesi yazma

Nota isimleriyle bona okuma

$\square$ Solfej parçalarını deşifre seslendirme

Solfej parçalarını tekrarlayarak ezberleme

Dizek üzerinde, notalarla (ritimli) ezgi diktesi yazma

Ezgilerin tonal analizini yapma

Tonal yapiya uygun ezgiler yaratma

$\square$ Diğer (varsa ekleyiniz): .....

11. Vermekte olduğunuz solfej eğitiminde öğrencilerin en fazla zorlandıkları çalışmalar sizce hangileridir? (BIRDEN FAZLA SEÇENEĞİ IŞARETLEYEBILLIRSINIZZ.)

Aralık tanıma-seslendirme

$\square$ Akor tanıma-seslendirme

$\square$ Dizi tanıma-seslendirme

Ritim kalıplarını okuma

$\square$ Ritim diktesi yazma

Derece numaralarıyla $(1,2,3, \ldots)$ yazılmış (ritimsiz) ezgi kalıplarını seslendirme

Derece numaralarıyla $(1,2,3, \ldots)$, (ritimsiz) ezgi kalıpları diktesi yazma

Dizek üzerinde, notalarla yazılmış (ritimsiz) ezgi kalıplarını seslendirme

Dizek üzerinde notalarla, (ritimsiz) ezgi kalıpları diktesi yazma

Nota isimleriyle bona okuma

Solfej parçalarını deşifre seslendirme

Solfej parçalarını tekrarlayarak ezberleme

Dizek üzerinde, notalarla (ritimli) ezgi diktesi yazma

$\square$ Ezgilerin tonal analizini yapma

$\square$ Tonal yapiya uygun ezgiler yaratma

$\square$ Diğer (varsa ekleyiniz): ......

12. Vermekte olduğunuz solfej eğitiminin değerlendirme (sınav) aşamasında, aşağıdakilerden hangilerine yer veriyorsunuz?

(BIRDEN FAZLA SEÇENEĞİ IŞARETLEYEBILIRSINIZZ.)

$\square$ Aralık tanıma-seslendirme

Akor tanıma-seslendirme

Dizi tanıma-seslendirme

$\square$ Ritim kalıplarını okuma

Ritim diktesi yazma 
Derece numaralarıyla $(1,2,3, \ldots)$ yazılmış (ritimsiz) ezgi kalıplarını seslendirme

Derece numaralarıyla $(1,2,3, \ldots)$, (ritimsiz) ezgi kalıpları diktesi yazma

$\square$ Dizek üzerinde, notalarla yazılmış (ritimsiz) ezgi kalıplarını seslendirme

Dizek üzerinde, notalarla (ritimsiz) ezgi kalıpları diktesi yazma

Nota isimleriyle bona okuma

$\square$ Solfej parçalarını deşifre seslendirme

$\square$ Solfej parçalarını tekrarlayarak ezberleme

$\square$ Dizek üzerinde, notalarla (ritimli) ezgi diktesi yazma

$\square$ Ezgilerin tonal analizini yapma

$\square$ Tonal yapıya uygun ezgiler yaratma

Diğer (varsa ekleyiniz): .....

13. Türkiye'de üniversite düzeyinde verilmekte olan solfej eğitiminin sonuçlarını, öğrenci başarısı açısından değerlendiriniz.

$\square$ Çok Düşük $\quad \square$ Orta-Düşük $\quad \square$ Orta $\quad \square$ Orta-Yüksek $\quad \square$ Çok Yüksek $\square$ Fikrim Yok

14. Sizin vermekte olduğunuz solfej eğitiminin sonuçlarını, öğrenci başarısı açısından değerlendiriniz.

$\square$ Çok Düşük $\quad \square$ Orta-Düşük $\quad \square$ Orta $\quad \square$ Orta-Yüksek $\quad \square$ Çok Yüksek

15. Sizin vermekte olduğunuz solfej eğitiminin daha bașarılı olmasını engelleyen nedenler, sizce nelerdir? (BİRDEN FAZLA SEÇENEĞ́̇ İŞARETLEYEBILLIRSINIIZ.)

Ders süresinin yetersizliği

Fiziksel şartların ve araç-gerecin yetersizliği

$\square$ Derse yönelik olarak hazırlanmış kitapların/kaynakların yetersizliği

Derse yönelik olarak hazırlanmış teknolojik yazılım ve uygulamaların yetersizliği

Derse yönelik olarak hazırlanmış etkili bir ders öğretim planının olmaması

$\square$ Öğrencilerin derse karşı olan ilgi ve motivasyonunun düşüklüğü

$\square$ Öğretim elemanı olarak benim, derse karşı olan ilgi ve motivasyonumun düşüklüğü

$\square$ Öğrencilerin temel bilgi ve beceri düzeyinin yetersizliği

$\square$ Öğretim elemanı olarak benim, solfej sistemlerine ve öğretim yöntemlerine yeterince hakim olmamam

$\square$ Diğer (varsa ekleyiniz): ..... 


\section{REFERENCES}

Apaydınlı, K. (2006). Anadolu güzel sanatlar liseleri müzik bölümü öğrencilerinin müziksel işitme-okuma-yazma dersinde karşılaştıkları sorunlar ve çözüm önerileri [The problems and the solution of suggestions which anatolian high school of fine arts students encounter in the musical hearing-reading and writing lesson] (Unpublished master's thesis). Turkey: Gazi University. Retrieved from https://tez.yok.gov.tr/UlusalTezMerkezi/

Brown, A. M. (1974). Letters syllables numbers intervals: Which music reading system is best for young children? Music Educators Journal, 61 (3), 52-55. Retrieved from http://www.jstor.org/stable/3394619

Daniels, R.D. (1986). Relationships among selected factors and the sight-reading ability of high school mixed choirs. Journal of Research in Music Education, 34 (4), 279-89. DOI: 10.2307/3345261

Ermiş, İ. (2009). Anadolu güzel sanatlar liselerinden mezun olan öğrencilerin müzik öğretmeni yetiştiren kurumlarda "müziksel işitme okuma ve yazma" alanındaki başarı durumlarmın değerlendirilmesi: Bursa örneği [The evaluation of the success level of the students who graduated from anotolian fine arts high schools in 'musical hearing reading writing' subject at the schools where music is taught as a profession: Bursa sample] (Unpublished master's thesis). Turkey: Haliç University. Retrieved from https://tez.yok.gov.tr/ UlusalTezMerkezi/

Floyd, E. \& Bradley, K. D. (2006). Teaching strategies related to successful sight-singing in Kentucky choral ensembles. Update: Applications of Research in Music Education, 25 (1), 70-81. DOI: 10.1177/ 87551233060250010108

Furby, V. J. (2008). Process and product: The sight-singing backgrounds and behaviors of first-year undergraduate students (Unpublished doctoral dissertation). USA: The Ohio State University. Retrieved from https://etd.ohiolink.edu/!etd.send_file?accession=osu1211160063\&disposition=inline

Iş1ldar, U. (2004). Müzik öğretmeni yetiştiren kurumlarda verilmekte olan müziksel işitme eğitimi dersinin değerlendirilmesi [Science of fine arts branch of education in musics] (Unpublished master's thesis). Turkey: Uludağ University. Retrieved from https://tez.yok.gov.tr/UlusalTezMerkezi/

Karahan, A. S. (2014). The evaluation of synchronous distance ear training compared to the traditional ear training. Eductional Research and Reviews, 9 (21), 1266-1274. DOI: 10.5897/ERR2014.1987

Karahan, A. S. (2016). Müzik öğretmenliği programı öğrencilerinin müziksel işitme okuma yazma eğitimi sürecindeki ders dışı çalışma yeterlilik durumlarının belirlenmesi [Determination of the competence of the music education program students' out-of-class activities in the process of ear training education] Ordu University Journal of Social Science Research, 6 (14), 8-26. Retrieved from https://dergipark.org.tr/ tr/pub/odusobiad/issue/27560/289959

Karasar, N. (1999). Bilimsel Araştırma Yöntemi, Ankara: Nobel Publishing.

Karkın, A. M. \& Baş, E. (2016). Başlangıç solfej ve dikte öğretiminde ezgi kalıpları modelinin uygulanması örneği. [Solfege and dictation in the teaching of initial melody patterns of the model example of implementation] İnönü University Journal of Art and Design, 6 (13), 199-209. Retrieved from https://dergipark.org.tr/tr/pub/iujad/issue/45229/566476

Komiyama, A. H. (2011). Examining the process of introducing the fixed-do system (Unpublished master's thesis). USA: Montana State University. Retrieved from https://scholarworks.montana.edu/xmlui/ handle/1/1661

Kuehne, J. M. (2007). A survey of sight-singing instructional practices in Florida middle-school choral programs. Journal of Research in Music Education, 55 (2), 115-128. DOI: 10.1177/002242940705500203 
Larson, S. (1993). The value of cognitive models in evaluating solfege systems. Indiana Theory Review, 14 (2), 73-116. Retrieved from www.jstor.org/stable/24045329

Nart, S. (2013). Deşifre şarkı söyleme eğitimine yönelik öğretim metodu önerisi [A recommended teaching method for sight-singing education]. Journal of Turkish Studies, 8 (3), 413-425. DOI: 10.7827/ TurkishStudies.4557

Norris, C. E. (2003). The relationship between sight singing achievement and melodic dictation achievement. Contributions to Music Education, 30(1), 39-53. Retrieved from http://www.jstor.org/stable/24127026

Özaltunoğlu, Ö. (2003). Solfej öğretim yöntemleri [Solfa teaching methods] (Unpublished master's thesis). Turkey: Dokuz Eylül University. Retrieved from https://tez.yok.gov.tr/UlusalTezMerkezi/

Özaltunoğlu, Ö. (2011). "Moveable - do" metodunun lisans öğrencilerinin dikte yazma becerilerinin geliştirilmesine etkisi [The effect of "moveable-do" method on development of graduate students' dictation skills] (Unpublished doctoral dissertation). Turkey: İnönü University. Retrieved from https://tez.yok.gov.tr/ UlusalTezMerkezi/

Özbek, Ö. (2003). Müzik teorisi ve işitme eğitiminde uygulamaların çeşitlendirilmesi [Diversification of applications in music theory and ear training] (Unpublished doctoral dissertation). Turkey: Marmara University. Retrieved from https://tez.yok.gov.tr/UlusalTezMerkezi/

Özdemir, O. (2019). Müziksel işitme okuma ve yazma dersinin ölçme-değerlendirme uygulamaları üzerine [A research on the measurement and evaluation applications of musical hearing reading and writing classes]. Afyon Kocatepe University Academic Music Research Journal, 5(9), 43-64. DOI: 10.5578/amrj.67910

Öztürk, B. M. (2010). Solfej öğretim yöntemlerinin Bando Okullar Komutanlı̆̆ı 9. Sinıf müziksel işitme okuma ve yazma derslerinde kullanulabilirliği [The use of solfege teaching techniques in 9th grade musical hearing, reading and writing classes in band schools] (Unpublished master's thesis). Turkey: Gazi University. Retrieved from https://tez.yok.gov.tr/UlusalTezMerkezi/

Reifinger, J. L. (2012). The acquisition of sight-singing skills in second-grade general music: Effects of using solfege and of relating tonal patterns to songs. Journal of Research in Music Education 60(1), 26-42. DOI: $10.1177 / 0022429411435683$

Sağer, T., Gürpınar E. \& Zahal, O. (2013). Müziksel işitme-okuma-yazma dersi ile diğer alan dersleri arasındaki ilişkilerin karşılaştırmalı olarak incelenmesi [Comparative examination of the relationships between musical hearingreading-writing lessons and other field lessons]. NWSA Fine Arts, 8 (2), 305-314. Retrieved from https://dergipark.org.tr/tr/pub/nwsafine/issue/19892/213033

Sisley, B. A. (2008). A comparative study of approaches to teaching melodic dictation (Unpublished master's thesis). USA: Kent State University. Retrieved from http://rave.ohiolink.edu/etdc/view?acc_num $=$ kent1216237008

Tufan, E. (2012). Birinci aşama müzik özel yetenek sınav sonuçlarının müziksel işitme okuma yazma dersi sonrasindaki durumu [The state of first stage special aptitude test scores at the completion of the musical hearing, reading and writing course]. NWSA Fine Arts, 7 (2), 214-225. Retrieved from https://dergipark.org.tr/tr/ pub/nwsafine/issue/19896/213077

Wunsch, I. G. (1973). Brainwriting in the theory class: The importance of perception in taking dictation. Music Educators Journal, 60 (1), 55-59. DOI: 10.2307/3394392

Yazan, E. İ. (2007). Konservatuvar şarkıcıllk lisans programlarında solfej eğitiminde izlenen kaynak ve yöntemlerin analizi [Analysing sources and methods used in solfege training at singer license program of conservatories] 
(Unpublished master's thesis). Turkey: Başkent University. Retrieved from https://tez.yok.gov.tr/ UlusalTezMerkezi/ 